\title{
1 A new species of the cheilostome bryozoan Chiastosella in the \\ 2 Southern Ocean, past and present
}

4 Federica Ragazzola ${ }^{1}$, Paul D. Taylor ${ }^{2}$, Pietro Bazzicalupo ${ }^{3}$, Beth Okamura ${ }^{4}$, Daniela N.

5 Schmidt $^{1}$

6

7

8

9

10

11

12

13

\footnotetext{
${ }^{1}$ School of Earth Sciences, University of Bristol, Wills Memorial Building, Queen's Road, BS8 1RJ, UK

${ }^{2}$ Department of Earth Sciences, Natural History Museum, Cromwell Road, London, SW7 5BD, UK

${ }^{3}$ Department of Earth Sciences, University of Florence, Via La Pira 4, Florence, Italy

${ }^{4}$ Department of Life Sciences, Natural History Museum, Cromwell Road, London, SW7 5BD, UK
}

\section{Abstract}

Understanding whether marine calcifying organisms may acclimatize to climate change is important with regard to their survival over the coming century. Because cold waters have a naturally higher $\mathrm{CO}_{2}$ uptake,the Southern Ocean provides an opportunity to study the potential impact of climate change. In 2011, anew cheilostome bryozoan species Chiastosella ettorina sp. nov. - was dredged from Burdwood Bank, Southern Ocean, at 300 metres depth during the Nathaniel B Palmer Cruise. C. ettorina had previously been collected in 1902 from the same area at 100 metres depth, but was incorrectly identified as Chiastosella watersi, which is an encrusting species from New Zealand. The availability of samples of the same species, from the same general location, but collected 109 years apart allowed us to investigate morphological modifications potentially arising from environmental changes. We found a significant difference in zooid size, with the oldest and shallowest specimens having smaller zooids than the recently collected, deeper specimens in disagreement with the temperature-size rule. This difference in zooid size appears to be unrelated to known sources of environmental variation such as temperature and salinity and it could represent the extremes of the zooid size range of C. ettorina. Analternative explanation is that the acidifying waters may cause zooids to grow more slowly, resulting in a final larger size. 
Keywords: Bryozoa, Taxonomy, Zooid Size, Ocean Acidificiation, Morphological Variation, Burdwood Bank, Climate Change

\section{Introduction}

There is a currently great interest in the predicted effect of climate change on calcifying marine organisms around the world. Climate change is an important factor in determining the past and future distributions of biodiversity (Rosenzweig et al. 2008). The high sensitivity of polar and sub-polar species to temperature increase and $\mathrm{pH}$ decrease renders the responses of taxa in these regions particularly important. Analyses of geographical distributional patterns of several groups of marine organisms (e.g., Clarke and Crame 1989; Gray 2001; Linse et al. 2006) have disproved the paradigm that biodiversity in all taxonomic groups decreases towards the poles (Sanders 1968). Indeed, some parts of the Southern Ocean, such as Burdwood Bank, seem to be hotspots for biodiversity, with an ever-increasing number of new species being discovered, from hydrocorals to gorgonians to (Häussermann and Försterra 2007; Zapata-Guradiola and López-González 2010; López-Gappa 2000). These discoveries contribute to the 700 additional new species described from the Southern Ocean since 2002, mostly from deep waters (Brandt et al. 2007).

Bryozoans comprise a phylum of benthic colonial invertebrates that are widely distributed throughout the world's oceans (Hayward and Ryland 1999; Wood et et al. 2012). They are a major component of the Southern Ocean benthos (Hayward 1995) and significant carbonate producers on the Antarctic shelf (Henrich et al. 1995). The phylum comprises about 5900 described living species, of which most belong to the order Cheilostomata (Bock and Gordon 2013). Bryozoan colonies demonstrate morphological differentiation of constitutent individuals, called zooids, with zooids specialised for feeding (autozooids), reproduction (ovicells and gonozooids) and defence (avicularia). Bryozoans are also capable of adopting appropriate morphological responses to environmental changes (McKinney and Jackson 1989) that can be expressed at genotypic or phenotypic levels. Differences in zooid size and shape, for example, have been related to growth rates, feeding resources, salinity, extreme hydrodynamic conditions, oxygen concentrations and temperature (Okamura 1992; O’Dea and Okamura 1999; Atkinson et al. 2006; O’Dea 2003; Okamura and Partridge 1999; Hunter and Hughes 1994). Many features, including general zooid size and shape, are fixed in the carbonate skeleton at the time that the zooid is budded (O'Dea and Okamura 2000). All these features make bryozoans valuable recorders of environmental changes in the present day as well as over geological time (e.g. O’Dea et al. 2011). 

Chiastosella ettorina, was collected from two different dredge hauls on the Burdwood Bank at a depth of 324-329 metres. It was the most abundant of bryozoans collected in these dredges together with Microporella sp.. The Burdwood Bank is a submerged plateau forming part of the Scotia Arc and located about $200 \mathrm{~km}$ south of the Falkland Islands. After examining the material it became evident that this new species had already been found on Burdwood Bank in 1902, but was misidentified in the literature (Hayward 1980). The discovery of these older specimens in the National Scottish Museum from the same location gave us the opportunity to compare the morphology of the species in samples collected 109 years apart.

Materials and methods

The study material from 2011 (six_colonies) obtained during a cruise of the RVIB Nathaniel B Palmer (11-03; May 9-June 11, 2011). The bryozoan colonies were collected using dredges at 324-219 metres depth on the Burdwood Bank (54²8.88's; 62¹8.08’ W). Historical material (one colony) originated from the Scotia (1902-1904) expedition, also collected on the Burdwood Bank, but at a shallower depth of $56 \mathrm{fms}$ ( 100 metres) (Fig.1).

Zooid size in a single colony was measured by randomly choosing 15 zooids outside the zone of astogenetic change (O'Dea \& Okamura 2000) and measuring their maximum lengths and maximum widths. The same procedure was used to measure size of 10 ovicells per colony. organic material and then prepared for scanning electron microscopy (SEM) using a CamScan-CS-44 at the University of Bristol and a low-vacuum microscope (LEO VP-1455) at the Natural History Museum, London. From the SEM images, three transects per colony were selected and zooid sizes were measured along these transects using ImageJ analysis software (Rasband 2008). For the historical material, SEM was carried out on one unbleached and uncoated colony using a low-vacuum microscope (LEO VP-1455) at the Natural History Museum, London. Replication of material for study was highly constrained by the lack of colonies sufficiently large to enable sampling zooid and ovicell sizes.

Surface areas (maximum length x maximum width) and elongation (maximum length/ maximum width) of both feeding zooids and ovicells from recent and historical material were 
compared using a Student's t-test. A Mann-Whitney Rank Sum Test was used to analyse ovicell surface areas since the data were not normally distributed.

Specimen repositories and their abbreviations are as follows: NHMUK, Natural History Museum, London; NSM, National Scottish Museum, Edinburgh; NMNH, National Museum of Natural History, Smithsonian Institution, Washington DC.

\section{Results}

\section{Taxonomy}

Family ESCHARINIDAE Tilbrook 2006

Genus CHIAStosella Canu \& Bassler, 1934

CHIASTOSELLA ETTORINA SP. NOV.

Synonymy: Chiastosella watersi (Stach, 1937): Hayward 1980, p. 704, fig. 1D.

Material: Holotype: NMNH ****. Paratypes: NHMUK ****, NSM 1921.143.1809 [material studied by Hayward]

Etymology: Named for the late father of the first author, Ettore Ragazzola.

Description: Colony erect, bilamellar, foliaceous, comprising broad fronds; large in size, with fragments up to $6 \mathrm{~cm}$ long. Colony base and early astogenetic stages unknown. Autozooids polygonal in outline, usually longer than broad $(\mathrm{L}=0.94 \pm 0.057 \mathrm{~mm}, \mathrm{~W}=0.86$ $\pm 0.0 .59 \mathrm{~mm}$, mean $\mathrm{L} / \mathrm{W}=1.05)(\mathrm{n}=50)$. Frontal shield evenly covered by small round pores, often missing from a tongue-shaped area proximal of the orifice. Primary orifice small, semicircular, usually wider than long $(\mathrm{L}=0.19 \pm 0.013 \mathrm{~mm}, \mathrm{~W}=0.27 \pm 0.005 \mathrm{~mm})(\mathrm{n}=50)$, with a rounded median sinus. Three to four oral spines developed. Ovicell helmet-like, hyperstomial, fairly prominent, as long as wide $(\mathrm{L}=0.43 \pm 0.02 \mathrm{~mm}, \mathrm{~W}=40 \pm 0.006 \mathrm{~mm})$ (n $=10$ ), with a narrow border containing a row of pores surrounding a central smooth, depressed area of entooecium. Spines lacking in ovicellate zooids. Bands of ovicells usually present, although rare isolated ovicells can be found. Avicularia adventitious, long, acute, usually situated along one or both of the distolateral edges of the polygonal autozooids and 
directed proximolaterally; rostrum acute and generally elevated at the tip; pivotal bar complete.

Remarks: This species was originally identified by Hayward (1980) as Chiastosella watersi Stach, 1937, an encrusting species from New Zealand. Aside from the erect, foliaceous colony-form, it differs in having considerably larger zooids (mean $\mathrm{W}=0.86 \mathrm{~mm}$ in $C$. ettorina vs. mean $\mathrm{W}=0.55 \mathrm{~mm}$ in C. watersi) (see Gordon 1989, p. 44, pl. 22E). Another important difference between the two species is orifice shape, which in C. ettorina lacks the straight proximal rim with a narrow, rectangular median sinus described for $C$. watersi. In contrast, the sinus in C. ettorina is rounded.

Paratypic material of this new species, originally identified by Hayward (1980) as $C$. watersi, was collected from Burdwood Bank at 103 metres depth between 1902 and 1904 (Fig. 2a, b). These specimens have smaller zooids than those collected in 2011 from 324 metres depth (Fig. 2c, d) $(\mathrm{L}=0.79 \pm 0.063 \mathrm{~mm}, \mathrm{~W}=0.70 \pm 0.041 \mathrm{~mm}$ vs. $\mathrm{L}=0.94 \pm 0.057$ $\mathrm{mm}, \mathrm{W}=0.86 \pm 0.059 \mathrm{~mm})$, but exhibit a similar orifice size $(\mathrm{L}=0.22 \pm 0.024 \mathrm{~mm}, \mathrm{~W}=$ $0.25 \pm 0.024 \mathrm{~mm}$ vs $\mathrm{L}=0.19 \pm 0.013 \mathrm{~mm}, \mathrm{~W}=0.27 \pm 0.006 \mathrm{~mm}$ ). Both the average surface area of the autozooids of $C$. ettorina and the surface area of the ovicells show a significant difference $(\mathrm{p}<0.001)$ between the recently collected $(0.85 \pm 0.07 \mathrm{~mm})$ and the historical material $(0.60 \pm 0.10 \mathrm{~mm})$ (Fig 3). The reduced size of the zooids could be ecophenotypic as the earlier collection was made from much shallower waters where the temperature is likely to have been higher. The size of bryozoan zooids is known to be inversely proportional to the temperature at which they are budded (Okamura et al. 2011) and smaller zooids therefore indicate warmer waters. However, the magnitude of the difference in this instance is large.

The new species $C$. ettorina is unusual for this genus in having erect, foliaceous colonies with broad fronds. This colony-form contrasts with the typically small encrusting colonies seen in other species, many of which occur in New Zealand and have been described or revised by Gordon (1989). It differs from Chiastosella umbonata Gordon, 1989 in having larger zooids (mean $\mathrm{W}=0.86 \mathrm{~mm}$ in $C$. ettorina vs. mean $\mathrm{W}=0.53 \mathrm{~mm}$ in $C$. umbonata) and a multiporous frontal shield; the frontal shield of C. umbonata Gordon, 1989 is largely smooth and imperforate. The new species lacks oral spines in ovicellate zooids but these are present and typically number two in both C. enigma Brown, 1954 and C. umbonata. The frontal shield has fewer pores in Chiastosella duplicata Gordon, 1989 and the autozooids may be larger (up to $1.07 \mathrm{~mm}$ long) but otherwise the zooidal morphology is quite similar to that of C. ettorina. A less porous frontal shield and larger zooids characterize Chiastosella 
exuberans Gordon, 1989 and this species also has tubercles on the frontal shield. In

Chiastosella dissidens Gordon, 1989 the frontal shield has only marginal pores and avicularia are lacking. Ovicellate zooids have distinctly larger orifices than infertile zooids in the Australian species Chiastosella daedala (MacGillivray, 1882); there is some indication that ovicellate zooids usually have somewhat larger orifices in C. ettorina but this is not consistent (see Fig. 2d). Chiastosella gabrieli Stach, 1937 has very large zooids (mean L = $1.30 \mathrm{~mm}$ in $C$. gabrieli $\mathrm{cf}$. $\mathrm{L}=0.94 \pm 0.057 \mathrm{~mm}$ in C. ettorina). In Chiastosella conservata (Waters 1881) the ovicell has a pair of pores in the proximal part of the endooecium and autozooidal frontal shields are sparsely porous (see Bock http://www.bryozoa.net/cheilostomata/escharinidae/chiacon.html).

Distribution: Burdwood Bank, Falkland Islands, South Atlantic.

Morphometric analyses

The average surface area of both the feeding zooids and the ovicells of $C$. ettorina showed significant differences (feeding zooids: $\mathrm{t}=7.128 ; \mathrm{p}<0.001$; ovicell: $\mathrm{t}=280.00 ; \mathrm{p}=<0.001$ ) between the recently collected $\left(0.95 \mathrm{~mm}^{2} \pm 0.02\right)$ and the historical material $\left(0.6 \mathrm{~mm}^{2} \pm 0.1\right)$ (Fig 5). In contrast, the elongation of both feeding zooids and ovicells did not show any significant differences between the recently collected and the historical material (feeding zooids: $\mathrm{t}=1.744 \mathrm{p}=0.087$; ovicell: $\mathrm{t}=187.00 ; \mathrm{p}=0.742$ ). Transects taken from three different colonies of similar size of the recently collected specimens showed no obvious cyclic pattern in the surface area of the feeding zooids (Fig. 3).

\section{Discussion}

In keeping with the temperature-size rule (Atkinson et al. 2006; O’Dea 2003), bryozoan zooids generally show an inverse relationship between temperature and size at the time of budding, larger zooids being formed in cooler waters. This makes it possible to infer seasonal variation in temperatures experienced by the bryozoan colonies by measuring within-colony variations in zooid size (O’Dea and Okamura 2000). Likewise, cyclical patterns in zooid size should be evident in transects, with peaks in size corresponding to the cold, winter season and small zooid sizes associated with the warm, summer season. However, parallel transects from different colonies of $C$. ettorina revealed no evidence for coordinated cyclical patterns in 
zooid size in the recently collected material (Fig. 3). This result was not surprising given the $\sim 0.6^{\circ} \mathrm{C}$ seasonal temperature difference (Southern Ocean Atlas 2004).

Unexpected, however, is the significant and surprisingly large difference in zooid size between the recently collected and the historical material, the former having appreciably larger zooids than the latter. Although the material comes from different depths (historical: 100 metres; recent: $219-324$ metres), the difference in annual temperature of $\sim 0.5^{\circ} \mathrm{C}$ (Fig. 4 ) between the two sites is similar to the seasonal variation at each site and was not associated with cyclicity in zooid size. As the historical material has smaller zooids (Fig. 5), this would imply a cooling trend between 1902 and 2011 in stark disagreement with a large body of work showing warming in the Southern Ocean (Meredith and King 2005; Turner et al. 2005). Furthermore, the difference in zooid size is surprisingly large, in the order of zooid size changes associated with changing thermal regimes of a much greater range. For instance, differences in zooid areas recorded for Conopeum seurati in the Severn Estuary (United Kingdom) during the summer and winter months (O'Dea and Okamura 1999) are roughly similar to those observed here for $C$. ettorina colonies from different depths (ratio of large:small zooid sizes approximately 1.5 and 1.4 for $C$. seurati and C. ettorina, respectively). However, the zooid size changes observed for $C$. seurati colonies were associated with an approximately $12{ }^{\circ} \mathrm{C}$ difference in temperature through the year. Similarly, seasonal patterns of zooid size variation (based again on ratio of large:small zooid sizes) in cupuladriid bryozoans are roughly 1.7 and 1.1 from the Pacific (temperature range $\sim 6^{\circ} \mathrm{C}$ ) and Caribbean (temperature range $\sim 2^{\circ} \mathrm{C}$ ) coasts of Panama, respectively (O'Dea and Jackson 2002). The opposite direction of zooid size change with time relative to the known difference in temperature and the magnitude of size variation observed here together imply that temperature is unlikely to explain directly the notable variation in zooid size in colonies collected during the two time periods.

Salinity is also unlikely to have influenced zooid size given the similar salinity profiles in the two collection sites (Fig. 4) over the time period and with depth. Water flow is another factor that can exert strong effects on zooid size. In particular, it has been shown that rapid flow regimes lead to a miniaturization along with changes in zooid shape (measured as zooid elongation) in bryozoan colonies (Okamura and Partridge 1999). Such miniaturization may be adaptive in effecting suspension feeding from similar flow microhabitats. However, zooid shape (as measured by zooid elongation) in C. ettorina is identical in the recent and historical material (Fig. 5 c), suggesting that variation in current flow is unlikely to explain 
our results. Furthermore, the increase in size from the historical to the modern material would be associated with a reduction in ambient flow regimes by a factor of $3 \mathrm{x}$ (Okamura and Partridge 1999). Even if sampling sites are located at the northern end of the ACC (Antarctic circumpolar current), with the AAOI (Antarctic oscillation index) indicating a strengthening and weakening of circumpolar westerly flow since 1920 (Jones and Widman 2004), we suggest this magnitude of difference in flow on regional scale is unlikely to characterise the depths (100 and 219-324 metres) from which colonies were collected for this study. It is possible that the observed, very large difference in zooid size could represent the extremes of the size range in C. ettorina if this species is particularly variable. Unfortunately this can only be ascertained by obtaining further specimens for examination. Alternatively, it may indicate phenotypic plasticity in response to some unidentified factor. An intriguing additional possibility is that acidifying waters may cause zooids to grow more slowly, resulting in a final larger size, particularly if acidification has an even stronger effect on development than on growth.

It would be desirable to obtain material from a range of depths at Burdwood Bank for morphological examination in order to characterise more fully the spectrum of morphological variation present in this species. Sequence data of course would also be highly informative. For the material presently at hand, it is likely to be difficult to obtain sequences from the historical samples that were probably subject to formaldehyde-based fixation at some stage, making DNA extraction and amplification highly problematic. Questions for future investigation include whether other Antarctic taxa exhibit similarly large ranges in zooid size at different depths and the influence of acidification on zooid size.

Acknowledgements We would like to thank the Master and the crew of Nathaniel B Palmer for facilitating the sampling. We thank Mary Spencer Jones (Department of Life Sciences, NHMUK) for arranging a loan of material from the NSM, and Suzanne Jennions for the collection of $C$. ettorina specimens during the Nathaniel B Palmer Cruise in 2011.This study was founded by the Leverhulme Trust (RPG-183 to DNS, PT and BO) and a Royal Society URF to DNS. 


\section{References}

254 Atkinson D, Morley SA, Hughes RN (2006) From cells to colonies: at what levels of body organization does the 'temperature-size rule' apply? Evolution \& Development 8 (2):202214.

Brandt A, Gooday AJ, Brandao SN, Brix S, Brokeland W, Cedhagen T, Choudhury M, Cornelius N, Danis B, De Mesel I, Diaz RJ, Gillan DC, Ebbe B, Howe JA, Janussen D, Kaiser S, Linse K, Malyutina M, Pawlowski J, Raupach M, Vanreusel A (2007) First insights into the biodiversity and biogeography of the Southern Ocean deep sea. Nature 447 (7142):307-311.

Bock PE, Gordon DP (2013) Phylum Bryozoa Ehrenberg, 1831. In Animal Biodiversity: An outline of higher-level classification and survey of taxonomic richness (addenda 2013). (Zhang Z-Q ed) Zootaxa 3703:67-74

Clarke A, Crame JA (1989) The origin of the Southern Ocean marine fauna. In: Crame JA

Publication, pp253-268

López-Gappa J (2000) Species richness of marine Bryozoa in the continental shelf and slope off Argentina (south-west Atlantic). Diversity and Distributions 6 (1):15-27.

271 GORDON DP (1989). The marine fauna of New Zealand: Bryozoa Gymnolaemata

272 (Cheilostomida Ascophora) from the western South Island continental shelf and slope. N.Z.

273 Oceanographic Institute Memoir 97

274 Gray J (2001) Antarctic marine benthic biodiversity in a world-wide latitudinal context. Polar 275 Biol 24 (9):633-641.

276 Häussermann V, Försterra G (2007) Extraordinary abundance of hydrocorals (Cnidaria, 277 Hydrozoa, Stylasteridae) in shallow water of the Patagonian fjord region. Polar Biol 30 278 (4):487-492. 
Hayward PJ (1980) Cheilostomata (Bryozoa) from the South Atlantic. Journal of Natural History 14 (5):701-721.

Hayward PJ, Ryland JS (1999) Cheilostomatous bryozoa. In: Barnes RSK, Crothers JH (eds) Synopses of the British Fauna (New Series). Field Studies Council, Shrewsbury

Henrich R, Freiwald A, Betzler C, Bader B, Schäfer P, Samtleben C, Brachert T, Wehrmann A, Zankl H, Kühlmann DH (1995) Controls on modern carbonate sedimentation on warmtemperate to arctic coasts, shelves and seamounts in the Northern Hemisphere: Implications for fossil counterparts. Facies 32

Hunter E, Hughes RN (1994) The influence of temperature, food ration and genotype on zooid size in Celleporella hyaline (L.). In:Hayward PJ, Ryland JS, Taylor Pd (eds) Biology and palaeobiology of bryozoans. Olsen and Olsen, Fredensborg, pp 83-86

Jones JM, Widmann M (2004) Early peak in Antarctic Oscillation index, Nature 432: 290291

Linse K, Griffiths HJ, Barnes DKA, Clarke A (2006) Biodiversity and biogeography of Antarctic and sub-Antarctic mollusca. Deep-Sea Res II 53:985-1008

McKinney FK, Jackson JBC (1989) Bryozoan evolution. Chicago University Press. Chicago Meredith MP, King JC (2005) Rapid climate change in the ocean west of the Antarctic Peninsula during the second half of the 20th century. Geophys. Res. Lett. 32 (19):L19604.

O’Dea A (2003) Seasonality and zooid size variation in Panamanian encrusting bryozoans. J. Mar. Biol. Ass. UK. 83:1107-1108

O’Dea A, Okamura B (1999) The influence of seasonal variation in temperature, salinity, and food availability on module size and colony growth in the estuarine bryozoan, Conopeum seurati. Mar. Biol. 135:581-588

O’Dea A, Okamura B (2000) Intracolony variation in zooid size in cheilostome bryozoans as a new technique for investigating palaeoseasonality. Palaeogeor. , Plalaeoclimatol., Palaeoecol. 126:61-74

O’Dea, A., Håkansson, E, Taylor, PD, Okamura B (2011) Environmental change prior to the K-T boundary inferred from temporal variation in the morphology of cheilostome bryozoans. Paleogeogr. Palaeoclimatol. Palaeoecol. 308: 502-512 
O’Dea A, Jackson JBC (2002) Bryozoan growth mirrors contrasting seasonal regimes across the Isthmus of Panama. Paleogeogr Palaeoclimatol Palaeoecol 185:77-94

Okamura B (1992) Microhabitat variation and patterns of colony growth and feeding in a marine bryozoan. Ecology 73(4):1502-1513

Okamura B, Partridge JC (1999) Suspension Feeding Adaptation to Extreme Flow Environments in a Marine Bryozoan. Biol. Bull. 196:205-215

Rasband WS (2008). Image J, Bethesda, MD: US National Institutes of Health, http://rsb.info.nih.gov/ij/.

Rosenzweig C, Karoly D, Vicarelli M (2008) Attributing physical and biological impacts to anthropogenic climate change. Nature 453: 353-357

Sanders HL (1968) Marine Benthic Diversity: a comparative study. Am. Nat. 102:243-282

Trenberth KE, Jones PD, Stocker TF, Ambenje P, Bojariu R, Easterling D, Tank AK, Parker D, Rahimzadeh F, Renwick JA, Rusticucci M, Soden B. et al. (2007). Observations: Surface and atmospheric climate change. In "Climate Change 2007: The Physical Basis. Contribution of Working Group I to the Fourth Assessment Report of the intergovernmental Panel on Climate Change. (Solom S, Qin D, Manning M, Chen Z, Marquis M, Averyt KB, Tignor M and Miller HL eds) 235-336 Cambridge University Press, Cambridge, UK.

Turner J, Colwell SR, Marshall GJ, Cope TAL, et al. (2005) Antarctic climate change during the last 50 years. Int. J. Climatol. 25:279-294

Wood ACL, Probert PK, Rowden AA, Smith AM (2012). Complex habitat generated by marine bryozoans: A review of its distribution, structure, diversity, threats and conservation. Aquatic Conservation, 22(4): 547-563

Zapata-Guardiola R, López-González PJ (2010) Two new gorgonian genera (Octocorallia: Primnoidae) from Southern ocean waters. Polar Biol. 33:313-320 


\section{$333 \quad$ Figure captions}

334 Fig. 1 Location of the sampling area.

335

336 Fig. 2 Scanning electron micrographs of Chiastosella ettorina sp. nov. from Burdwood Bank.

337 (a), (b) holotype colony (NMNH *****) collected in 2011; (a) Part of colony with reparative 338 growth of zooids on the left side from a fracture running vertically through the centre of the image; (b) three ovicellate zooids (O) and scattered small avicularia (A). (c), (d) Paratype colony (NMSZ 1921.143.1809); (c) Part of unbleached colony with opercula closing autozooidal orifices; (d) Transverse band of ovicells.

342 Fig. 3 Zooid surface areas sampled alongtransects from the distal, recently-developed zooids at colony edges to progressively older zooids away from colony edges in three different colonies of Chiastosella ettorina that were alive at the time of collection in 2011.

Fig. 4 Hydrological parameters for the two different collecting sites for Chiastosella ettorina (Ocean Data View). The triangle is the 1902 collection site and the square the 2011 collection site. The bands display the depth of the 1902 sample and the depth of the 2011 sample.

348 Fig. 5 Mean surface areas and elongation of autozooids (a, c) and ovicells (b, d) of 349 Chiastosella ettorina sp. nov. from Burdwood Bank collections made during 2011 at 324350319 m depth and 1902 at $\sim 100$ metres depth ( $n=15$ zooids from six different colonies and 351 from a single colony, respectively; error bars = standard deviations). 


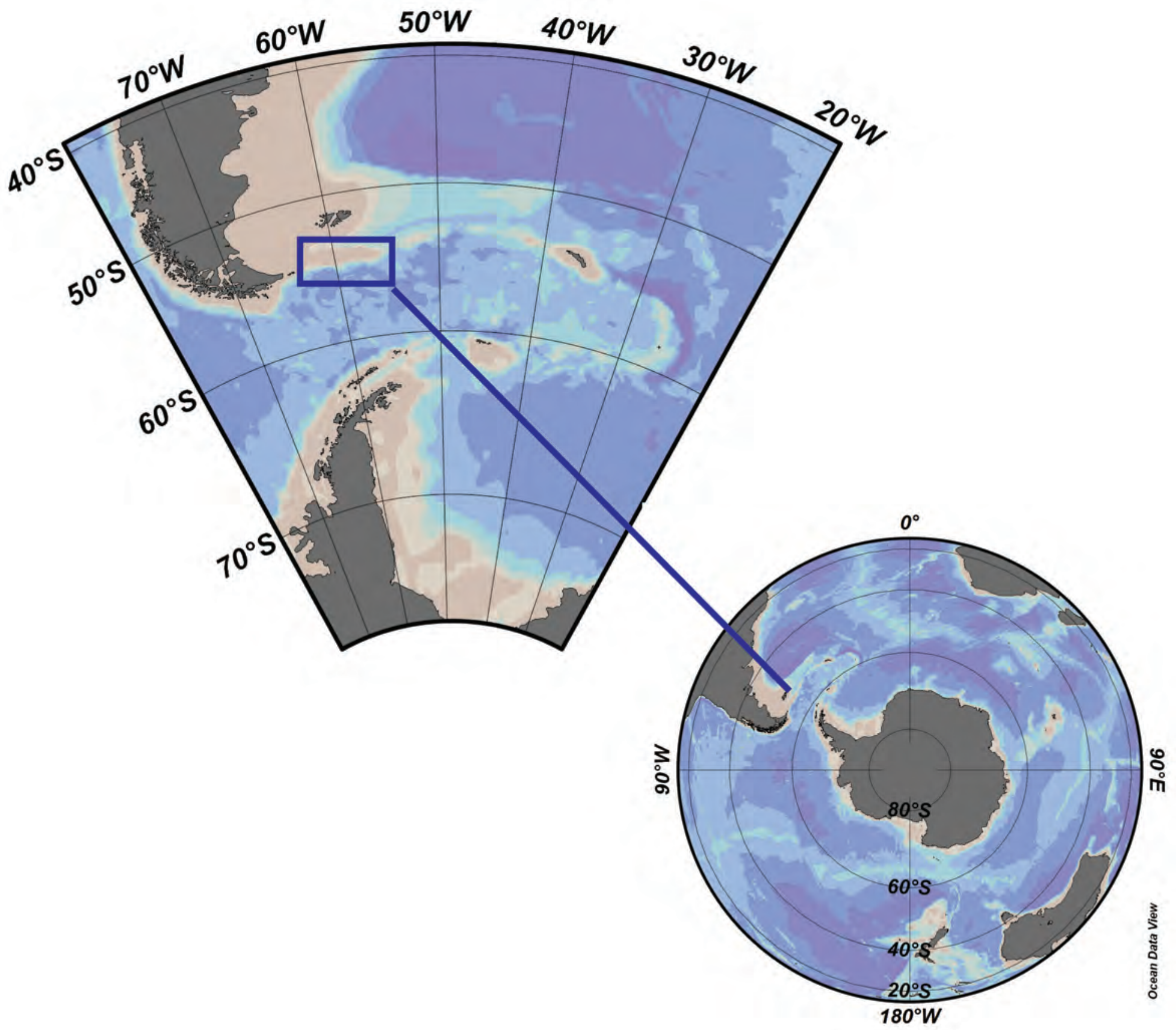



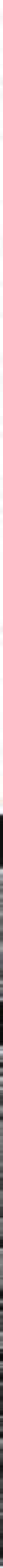

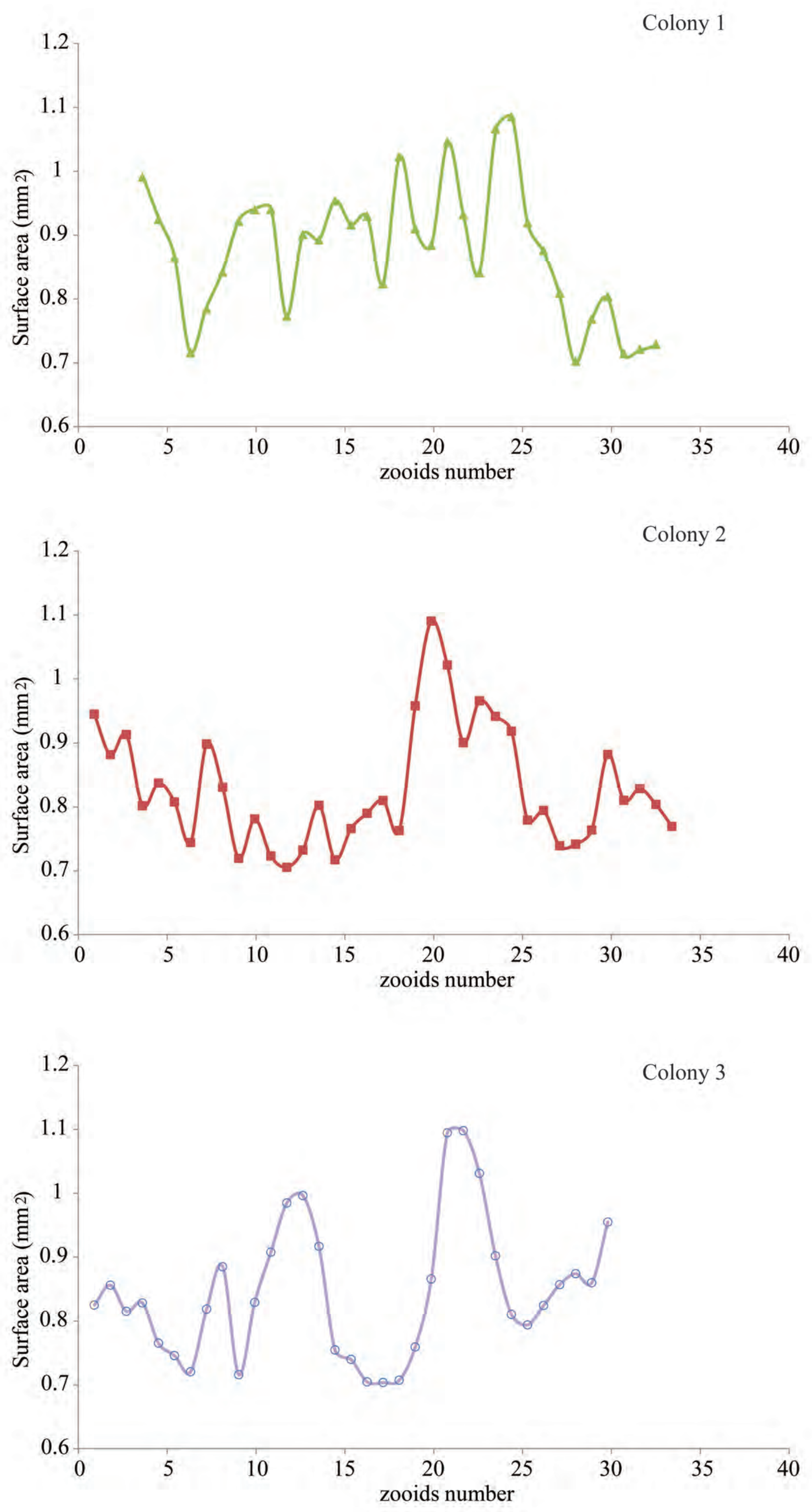
2011

A 1904
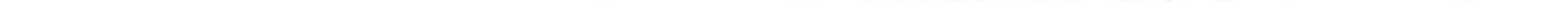
